\title{
PEMIKIRAN HADIS KH. M. HASYIM ASY'ARI DAN KONTRIBUSINYA TERHADAP KAJIAN HADIS DI INDONESIA
}

\author{
Afriadi Putra \\ Mahasiswa Pascasarjana UIN Sunan Kalijaga Yogyakarta \\ J1. Marsda Adisucipto, Yogyakarta, Daerah Istimewa Yogyakarta 55281, Indonesia \\ Alumni Pondok Pesantren Darun Nahdhah Thawalib Bangkinang Riau \\ E-mail: adismart89@gmail.com
}

\begin{abstract}
This article describes the opinion of KH. M. Hasyim Asy'ari, one of the Indonesian Hadith scholars, and his contribution to the study of Hadith in Indonesia. This study is important to understand the dynamic of Hadith study in Indonesia that experienced stagnancy for certain period. The twentieth century marked as the rising of Hadith study in Indonesia by the emergence of many Hadith books of Arabic languages, their translations and the scholars opinion related to Hadith. The book of risālah ahlu al-sunnah wa al-jamā'ah is among those books that was written in the beginning of the twentieth century. This book played a significant role at that time as a guidance for Muslim society in facing modernity. The content of this book provides basic themes related to religious experiences of the community. This book is also represented the opinion of KH. M. Hasyim Asy'ari related to Hadith, as an Indonesian Muslim scholar who received isnäd Hadith (the chain of Hadith transmission) from his teacher Syeikh Mahfudz Termas.
\end{abstract}

Keywords:

Hasyim Asy'ari; risālah; Hadith study; Indonesia.

\begin{abstract}
Abstrak
Tulisan ini membahas pemikiran tokoh ahli hadis, yaitu KH. M. Hasyim Asy'ari dan kontribusinya terhadap kajian hadis di Indonesia. Kajian ini penting untuk melihat dinamika studi hadis di Indonesia yang sempat mengalami masa vakum. Abad ke-20 menjadi titik bangkitnya kajian hadis yang ditandai dengan munculnya kitab-kitab hadis berbahasa Arab, terjemahan dan hasil pemikiran dari tokoh ahli hadis. Kitab risālah ahlu al-sunnah wa al-jamā'ah merupakan salah satu kitab yang ditulis pada awal abad ke-20. Kitab ini memainkan peranan yang cukup penting ketika itu sebagai pedoman bagi umat Islam menghadapi benturan modernitas. Isi kandungannya membahas tematema pokok yang berkaitan langsung dengan keberagamaan masyarakat. Kitab ini juga menjadi representasi dari pemikiran hadis KH. M. Hasyim Asy’ari sebagai ulama hadis Indonesia yang mendapat isnād (mata rantai) hadis dari gurunya, Syeikh Mahfudz Termas.
\end{abstract}

Kata Kunci:

Hasyim Asy'ari; risālah; studi Hadis; Indonesia.

DOI: http://dx.doi.org/10.15575/jw.v39i1.577

Received: January 2015 ; Accepted: December 2015 ; Published: February 2016

\section{A. PENDAHULUAN}

Kajian hadis di Indonesia sudah dimulai pada abad ke-17 Masehi, ditandai dengan munculnya kitab Hidâyah al-Habīb fí Targhīb wa al-Tarhīb yang ditulis oleh Nuruddin alRaniri. ${ }^{1}$ Dilanjutkan dengan munculnya kitab

\footnotetext{
${ }^{1}$ Nama lengkapnya adalah Nūr al-din Muhammad bin 'Ali bin Hasanji al-Hamīd al-Syafi' 'i al-'Aydarushi al-Ranirì. Dilahirkan di Ranir (sekarang Randir, Gujarat) pada akhir abad ke-16 dari ibu seorang Melayu dan ayah keluarga imigran Hadhrami. Ia datang ke Aceh tahun 1637 dan ditunjuk sebagai Syekh al-Islam oleh Kesultanan Aceh. Lihat Azyumardi Azra, Jaringan
}

Hadis 'Arba'in (empat puluh hadis karya alNawawi) dan kitab al-Mawa'id al-Badi'ah, sebuah koleksi hadis qudsi yang ditulis oleh Abd Rauf al-Sinkili². Perkembangan selanjut-

Ulama Timur Tengah dan Kepulauan Nusantara Abad XVII \& XVIII; Akar Pembaruan Islam di Indonesia (Jakarta: Kencana, 2013), 210.

${ }^{2}$ Beliau adalah 'Abd al-Rauf bin 'Ali al-Jāwì alFansuri al-Sinki $\bar{i}$, sebagaimana terlihat dari namanya, ia adalah seorang Melayu dari Fansur, Sinkil (sekarang Singkel, Nangroe Aceh Darussalam). Menurut D. A. Rinkes sebagaimana yang dikutip oleh Azra, Al-Sinkili dilahirkan sekitar tahun $1024 \mathrm{H} / 1615 \mathrm{M}^{2}$. Al-Sinkili meninggal dunia pada tahun $1105 \mathrm{H} / 1693 \mathrm{M}$ pada usia 
nya kajian hadis di Indonesia memasuki masa vakum, hal ini dilatarbelakangi oleh kondisi bangsa Indonesia yang dijajah oleh Belanda. Sikap agresif dan intimidatif Belanda sangat berdampak pada perkembangan ilmu pengetahuan. Barulah pada akhir abad ke-19 atau memasuki abad ke-20 ditemukan kitab hadis yang disusun oleh ulama Indonesia, yaitu $\mathrm{KH}$. Mahfudh Termas ${ }^{3}$ dengan kitabnya yang berjudul; Manhāj Dhawi al-Nazar yang ia tulis ketika ia berada di Mekkah. ${ }^{4}$ Barulah mulai abad ke-20 kajian hadis di Indonesia mulai memperlihatkan kemajuan yang cukup signifikan.

Secara umum, kajian hadis di Indonesia seperti halnya kajian hadis kalangan mutaqaddimin terdiri dari dua fokus besar, yaitu: hadis dan ulumul hadis. Adapun bentuknya ada yang berupa terjemahan dari kitab berbahasa Arab dan ada juga yang merupakan karangan pemikiran sendiri seorang tokoh. Kitab hadis yang ditulis dijadikan sebagai pedoman untuk melakukan ritual ibadah, namun ada juga kitab hadis yang ditulis untuk merespons keadaan tertentu di kalangan masyarakat, misalkan kitab Risālah Ahlu alSunnah wa al-Jamā'ah yang ditulis oleh seorang ulama yang berpengaruh dan ahli di bidang hadis, yaitu: KH. M. Hasyim Asy’ari.

78 tahun dan dimakamkan di Kuala Aceh. Lihat Azra, Jaringan Ulama Timur Tengah dan Kepulauan Nusantara Abad XVII \& XVIII; Akar Pembaruan Islam di Indonesia, 239.

${ }^{3}$ Beliau adalah ulama sekaligus ahli hadis asal Indonesia, nama lengkapnya Muhammad Mahfud ibn 'Abdullah ibn 'Abd al-Mannan al-Ṭirmashì. Ia dilahirkan tahun $1842 \mathrm{M}$ di desa Termas, Arjosari, Pacitan, Jawa Timur. Sejak kecil ia diutus ayahnya untuk belajar di Mekkah, di sana ia mendalami bidang hadis dan fikih sehingga ia mendapatkan isnad (mata rantai) yang sah dalam transmisi intelektual penyampaian hadis Bukhari urutan ke-23 yang mendapat ijazah dari gurunya. Meskipun ia menolak pulang ke Indonesia, namun kontribusinya sangat besar dengan menjadi guru dari sejumlah tokoh di Indonesia seperti; Hasyim Asy'ari, Wahab Hasbullah, Mas Mansur dan lain sebagainya. Lihat M. Bibit Suprapto, Ensiklopedi Ulama Nusantara (Jakarta: Gelegar Media Indonesia, 2009), 464-466.

${ }^{4}$ Muhammad Maḥfud Ibn 'Abdullah al-Ṭirmashí, Manhaj Dhawi al-Nazar (Surabaya: Ahmad Ibn Sa'ad Ibn Nabhan, 1974), 1.
Kitab ini muncul sebagai respons dari kondisi keberagamaan masyarakat ketika itu.

Menurut hemat penulis, ada dua alasan yang menjadi dasar pentingnya pembahasan tentang pemikiran KH. M. Hasyim Asy'ari ini yaitu, Pertama, ia dipandang sebagai ulama berpengaruh dan seorang ahli hadis yang mendapat isna $\bar{d}$ (mata rantai) transmisi hadis dari gurunya Mahfudh Termas, sehingga ia sangat berkompeten menulis karya dalam bidang hadis. Kedua, kitab Risālah Ahlu alSunnah wa al-Jamā'ah yang ia tulis sangat berpengaruh dan menjadi rujukan utama dalam kajian hadis ketika itu, kitab ini juga berperan sebagai filtrasi terhadap fenomenafenomena keberagamaan yang berkembang di kalangan masyarakat menghadapi tantangan modernitas. Tulisan ini akan membahas tentang pemikiran Hasyim Asy'ari dalam bidang hadis yang dapat dilacak dari kitab yang dikarangnya, disamping itu penulis juga akan menganalisis kontribusi Hasyim Asy'ari bagi kajian hadis di Indonesia ketika itu dan era selanjutnya.

\section{B. HASIL DAN PEMBAHASAN \\ 1. Latar Historis KH. M. Hasyim Asy'ari a. Ulama Modernis yang Ahli Hadis}

Ulama yang dikenal sebagai pribadi sederhana ini bernama Muhammad Hashim Ash'ari ibn 'Abd al-Wahìd ibn 'Abd alHalim, selanjutnya disebut Hasyim Asy'ari. Beliau dilahirkan di Desa Gedang, Jombang, Jawa Timur, tanggal 24 Dhulqaidah $1287 \mathrm{H}$ (14 Februari 1871 M.). Ayahnya, Asy'ari adalah pendiri Pesantren Keras, 8 KM dari Jombang. Sementara kakeknya Kyai Usman, adalah Kyai terkenal dan pendiri Pesantren Gedang di Jombang yang didirikan tahun 1850-an ${ }^{5}$. Sedangkan dari pihak ibu, masih keturunan Raja Brawijaya, seorang raja di Pulau Jawa. Dipercaya bahwa ia keturunan Raja Muslim Jawa, Jaka Tingkir, dan Raja Hindu Majapahit, Barawijaya VI. Jadi,

\footnotetext{
${ }^{5}$ Abuddin Nata, Tokoh-tokoh Pembaharuan Pendidikan Islam di Indonesia (Jakarta: Raja Grafindo Persada, 2005), 113.
} 
Hasyim Asy'ari juga dipercaya merupakan keturunan bangsawan. ${ }^{6}$

Hasyim Asy'ari dibesarkan di tengahtengah keluarga yang sangat memegang teguh ajaran Islam dengan tradisi pesantren yang sangat kuat. Untuk memudahkan memahami perjalanan hidup beliau, penulis akan memetakannya ke dalam beberapa periode sebagai berikut;

Periode Pertama, masa anak-anak sampai remaja. Pada masa ini beliau dididik dan dibesarkan di bawah bimbingan orang tua dan kakeknya di pesantren Gedang. Ia mendapat pelajaran dasar-dasar tauhid, fikih, tafsir dan hadis. Selanjutnya ketika ia berumur lima tahun ayahnya mendirikan pesantren Keras, sebelah selatan kota Jombang. Selama di pesantren ini Hasyim Asy'ari sudah memperlihatkan bakat kecerdasannya dengan menjadi guru pengganti (badal) dengan mengajar murid-murid yang tidak jarang lebih tua dari umur beliau sendiri. Pendidikan beliau tidak hanya di pesantren Gedang, tercatat beliau juga mengembara ke beberapa pesantren di Jawa dan Madura, seperti Pesantren Wonokoyo (Probolinggo), Pesantren Langitan (Tuban), Pesantren Trenggalis dan Kademangan (Bangkalan, Madura) dan pesantren lainnya.

Pada masa muda Hasyim Asy'ari, ada dua sistem pendidikan bagi penduduk pribumi Indonesia. Pertama sistem pendidikan pesantren, bagi para santri muslim dengan fokus pengajaran ilmu agama. Kedua sistem pendidikan Barat pemerintah kolonial Belanda, dengan tujuan menyiapkan para siswa untuk menempati posisi-posisi administrasi pemerintah baik tingkat rendah maupun tingkat menengah. Namun sekolah ini sangat terbatas sehingga mayoritas penduduk pribumi yang sebagian besar muslim tidak mendapat kesempatan.

Setelah mendapatkan pendidikan di pesantren di bawah bimbingan orang tua dan kakeknya sampai remaja, Hasyim Asy'ari juga mengembara ke berbagai pesantren di Jawa dan Madura, mengingat ketika itu sudah lazim para santri mengikuti pelajaran di berbagai pe-

\footnotetext{
${ }^{6}$ Latiful Khuluq, Kebangunan Ulama “Biografi KH. Hasyim Asy'ari” (Yogyakarta: LKiS, 2000), 17.
}

santren karena masing-masing pesantren mempunyai spesialisasi dalam pengajaran ilmu agama seperti yang juga dilakukan oleh KH. Wahab Hasbullah. ${ }^{7}$

Pada tahun 1893 M. Hasyim Asy'ari kemudian melanjutkan pendidikan di Mekah selama 7 tahun di bawah bimbingan Syaikh Mahfudh dari Termas, ulama Indonesia yang pertama mengajar Shahih Bukhari di Mekkah ${ }^{8}$. Syaikh Mahfudh adalah seorang yang ahli dalam ilmu hadis, darinya Hasyim Asy'ari mendapatkan ijazah mengajar Shahih Bukhari yang merupakan pewaris terakhir dari pertalian penerima (isnād) hadis dari 23 generasi penerima karya ini. Syaikh Mahfudh juga membuat Hasyim Asy'ari sangat tertarik dengan ilmu ini sehingga setelah kembali ke Indonesia, ia mendirikan pesantren yang terkenal dalam pengajaran hadis. Hasyim Asy'ari juga belajar tarekat Qadariyah dan Naqsabandiyah, ilmu yang diterima dari Syaikh Mahfudh dan Nawawi.

Hasyim Asy'ari juga belajar fikih mazhab Syafi'i di bawah bimbingan Ahmad Khatib yang juga ahli dalam bidang astronomi dan ilmu falak. Selain itu, pada akhir abad ke-19 M. perkembangan Islam di Timur Tengah menimbulkan adanya gerakan menuju kebangkitan dunia Islam di bawah komando Jamaluddin al-Afgani dan Mohammad Abduh yang bertujuan mewujudkan semangat pembaharuan, menanamkan jiwa anti imperialisme dan kolonialisme serta reformasi menentang kezaliman penjajah serta mengharapkan kebebasan Islam di masa yang akan datang.

Di Hijaz, Hasyim Asy'ari juga mendapat pengaruh dan perkembangan politik lokal seperti sentimen anti-kolonial, nasionalisme Arab dan pan-Islamisme sebagai reaksi terhadap invasi Barat pada abad ke-19 oleh Kristen Eropa. Anjuran pan-Islamisme adalah agar umat Islam bersatu dalam menghadapi ekspansi Eropa. Seruan persatuan ini nampaknya sangat berpengaruh pada Hasyim Asy'ari dan

${ }^{7}$ Zamakhsyari Dhofier, Tradisi Pesantren Studi Tentang Pandangan Hidup Kyai (Jakarta: LP3ES, 1994), 50.

${ }^{8}$ Badiatul Roziqin, 101 Jejak Tokoh Islam Indonesia (Yogyakarta: e-Nusantara, 2009), 247. 
mengilhaminya untuk mewujudkan persatuan umat Islam dengan membebaskan tanah air dari kolonialisme. ${ }^{9}$

Setelah cukup lama menuntut ilmu di Mekkah, Hasyim Asy'ari memutuskan kembali ke tanah air. Di Indonesia beliau mendirikan pesantren Tebuireng pada tahun $1899 \mathrm{M}$.

Tidak hanya melalui pendidikan dan pesantren, Hasyim Asy'ari juga mendirikan organisasi masa (Ormas) Islam yang dikenal dengan Nahdhatul Ulama (NU), didirikan pada tanggal 31 Januari 1926. Hasyim Asy'ari juga berjasa dalam menyatukan organisasi Islam yang sebelumnya berseteru ke dalam satu wadah organisasi. Ia menyerukan persatuan dan kesatuan umat Islam sebagai cara menghadapi taktik pecah belah oleh Belanda.

Periode Kedua, masa berkeluarga sampai akhir hayat. Semasa hidup, Hasyim Asy'ari tercatat menikah sebanyak 7 kali. Di usianya yang menginjak 21 tahun beliau menikah dengan Nafisah putri Kyai Ya'kub dari Pesantren Siwalan Panji (Sidoarjo) dan melaksanakan ibadah haji dengan istri dan mertuanya. Tujuh bulan di Mekah, istri beliau meninggal dan setahun setelahnya beliau memutuskan untuk kembali ke Indonesia. Di Indonesia, kemudian beliau menikah lagi dengan Khadijah dari Karangkates (Kediri). Pernikahan kedua ini tidak berlansung lama, karena istrinya meninggal dunia. Selanjutnya ia menikah dengan Nafiqah dari Sewulan (Madiun). Dari hasil perkawinannya dengan Nafiqah Hasyim Asy'ari mendapatkan sepuluh orang anak, yaitu: Hannah, Khoiriyah, Asiyah, Azzah, Abdul Wahid (yang lebih dikenal dengan Wahid Hasyim), Abdul Hakim (Abdul Kholik), Abdul Karim, Ubaidillah, Mashuroh, dan Muhammad Yusuf. Perkawinan Hasyim Asy'ari juga berhenti di tengah jalan, karena Nafiqah meninggal dunia pada tahun 1920 M.

Sepeninggal Nafiqah, Hasyim Asy'ari menikah lagi dengan Masrurah dari Kapurejo, Pagu (Kediri). Dari hasil perkawinan keempatnya ini, Hasyim Asy'ari memiliki empat orang anak: Abdul Qadir, Fatimah, Khodijah, dan

\footnotetext{
${ }^{9}$ Harun Nasution, Pembaharuan dalam Islam; Sejarah Pemikiran dan Gerakan (Jakarta: Bulan Bintang, 2003), 43.
}

Muhammad Ya'kub. Perkawinan dengan Nafiqah ini merupakan yang terakhir bagi beliau hingga akhir hayatnya. ${ }^{10}$

Menurut berbagai sumber, Hasyim Asy'ari meninggal dunia pada tanggal 27 Juli 1947 akibat penyakit darah tinggi atau stroke setelah menerima kabar tentang kondisi Republik Indonesia saat itu. Sebelumnya, pada tanggal 2 Juli 1947, datang utusan Bung Tomo dan Jenderal Sudirman untuk menyampaikan kabar perihal agresi Militer Belanda I. Dari keduanya, diperoleh kabar bahwa pasukan Belanda yang membonceng Sekutu pimpinan Jenderal SH. Poor telah berhasil mengalahkan tentara Republik Indonesia dan menguasai wilayah Singosari (Malang). Tidak hanya itu, pasukan Belanda juga menjadikan warga sipil sebagai korban, sehingga banyak di antara mereka meninggal dunia.

\section{b. Karya-karya KH. M. Hasyim Asy'ari}

Hasyim Asy'ari termasuk seorang penulis yang produktif. Sebagian besar ia menulis dalam Bahasa Arab dalam berbagai bidang ilmu seperti tasawuf, fikih dan hadis. Sampai sekarang sebagian kitab ini masih dipelajari di berbagai pesantren. Adapun karya-karya Hasyim Asy'ari yang cukup terkenal dan berkaitan dengan kajian ini antara lain:

1. Adab al-'Alim wa al-Muta'allim, yaitu kitab yang berisi tentang akhlak guru dan murid

2. Risālah Ahl al-Sunnah wa al-Jamā'ah fi Hadith al Mawta wa Ashrat al-Sa'ah wa Bayan Mafhūm al-Sunnah wa al-Bid'ah, (Risalah ahlus sunnah wal jama'ah: mengenai hadis-hadis tentang kematian dan tanda-tanda hari kiamat serta penjelasan mengenai sunnah dan bid'ah)

3. Ziyadah al-Ta'liqat 'ala Manzumāt alShaikh 'Abd Allah ibn Yasin al-Fasuruani. Catatan tambahan mengenai syair Syaikh 'Abdullah bin Yasin Pasuruan, berisi bantahan Hasyim Asy'ari terhadap kritikan Syaikh 'Abdullah bin Yasin Pasuruan terhadap Nahdlatul Ulama

\footnotetext{
${ }^{10}$ Achmad Muhibbin Zuhri, Pemikiran KH. Hasyim Asy'ari tentang Ahl Al- Sunnah Wa Al Jama'ah (Surabaya: Khalista, 2010), 74-75.
} 
4. Al- Tanbihat al-Wajibah, nasihat penting bagi orang yang merayakan kelahiran Nabi Muhammad dengan menjalankan hal-hal yang dilarang agama

5. Al-Risalah fí al-Aqā'id, (Risalah tentang keimanan)

6. Al-Hadith al-Mawt wa Ashrah al-Sa'ah. Hadis mengenai kematian dan kiamat. Dan banyak lagi karya-karya yang lainnya. ${ }^{11}$

Selain itu, pidato-pidato Hasyim Asy'ari diterbitkan dalam berbagai surat kabar seperti Soeara Nahdhatul Ulama, Soeara MIAI; dan Soeara Moeslimin Indonesia yang diterbitkan Masyumi. Dan masih banyak lagi karya beliau yang sampai saat ini masih dipelajari di berbagai pesantren di Indonesia.

\section{Kitab Risalah Ahl Al-Sunnah Wal Al- Jama'ah: Kontribusi Hasyim Asy'ari Terhadap Kajian Hadis Indonesia}

Pemikiran Hasyim Asy'ari tidak bisa lepas dari bidang keilmuan yang ditekuninya selama menuntut ilmu di Mekkah, di mana selama berada di Tanah Suci beliau berguru kepada seorang ahli hadis yang sangat masyhur ketika itu, Syaikh Mahfud Termas. Gurunya itu menjadi sosok inspiratif dan mempengaruhi pola pemikirannya. Karya-karya yang ditulis Hasyim Asy'ari cukup banyak seputar hadis, tasawuf dan fikih. Kitab hadis karya beliau yang cukup terkenal adalah Risālah Ahl alSunnah wa al-Jamā'ah, kitab ini ditulis antara tahun 1920 - 1930-an. ${ }^{12}$

Kitab ini menjadi kitab kunci untuk mempelajari pemikiran hadis Hasyim Asy'ari. Secara lebih detail penulis akan membahas pemikiran hadis Hasyim Asy'ari yang berkisar tentang sunnah dan bid'ah.

\footnotetext{
${ }^{11}$ Samsul Nizar dan Ramayulis, Ensiklopedi Tokoh Pendidikan Islam di Indonesia (Jakarta: Raja Grafindo Pustaka, 2005), 217.

${ }^{12}$ Nama lengkap kitab ini adalah; Risalah ahl alSunnah wa al-Jamā'ah fï Hadith al Mawta wa Ashrat al-Sa'ah wa Bayan Mafhüm al-Sunnah wa al-Bid'ah. Dicetak di Jombang, Jawa Timur oleh penerbit Maktabah al-Turath al-Islami, edisi baru kitab ini dicetak tahun 1996.
}

\section{a. Latar Belakang Penyusunan}

Berdasarkan penelusuran penulis, Hasyim Asy'ari tidak menyebutkan alasan spesifik yang melatarbelakangi penulisan kitab ini. Namun, jika dikaitkan dengan konteks bangsa Indonesia ketika itu jelas terlihat adanya hubungan ditulisnya kitab ini dengan kondisi keberagamaan umat Islam Indonesia. Sejarah mencatat, pada awal abad ke-20 umat Islam di Indonesia mulai menunjukkan perjuangan yang gigih untuk mendapatkan kemerdekaan dari penjajah Belanda. Hal ini dilatarbelakangi oleh pemikiran-pemikiran pembaharuan yang mulai didengung-dengungkan oleh tokohtokoh modernis Timur Tengah seperti Jamaluddin al-Afghani, Muhammad Abduh, Rasyid Ridha dan lain sebagainya.

Pemikiran pembaharuan yang dipelopori oleh tokoh-tokoh di atas tentu sangat mempengaruhi pemikiran umat Islam di Indonesia. Akan tetapi, tidak semua pemikiran tokohtokoh tersebut sesuai dengan kondisi masyarakat. Salah satu dampak yang dapat dilihat yaitu, banyaknya di antara kepercayaan dan amalan Muslim tradisional dianggap sebagai bid'ah. Amalan-amalan yang sudah mengakar di kalangan masyarakat seperti tahlilan, slametan $^{13}$, talqin $^{14}$, dan ziarah dianggap sesuatu yang telah menyimpang dari ajaran Islam yang sesungguhnya. Tidak hanya itu pengetahuan dan posisi kyai sebagai "rujukan" dalam praktik keberagamaan juga dikritik, karena itu adalah taqlid buta.

Berdasarkan konteks keberagamaan seperti itu, Hasyim Asy'ari sebagai salah seorang tokoh modernis dari "kalangan dalam" merasa bertanggungjawab memberikan pencerahan

\footnotetext{
${ }^{13}$ Slametan yaitu upacara ritual komunal yang telah mentradisi di kalangan masyarakat Islam Jawa yang dilaksanakan untuk peristiwa penting dalam kehidupan seseorang, seperti; kelahiran, kkematian, pernikahan, membangun rumah dan lain sebagainya. Lihat Ahmad Khalil, Islam Jawa, Sufisme dalam Etika dan Tradisi Jawa (Malang: UIN Malang Press, 2008), 278.

${ }^{14}$ Talqin berarti mengajarkan kepada orang lain kalimat syahadat dengan cara membisikkan atau mengingatkan kalimat tauhid La ilāha illa Allah kepada orang yang sedang sakaratul maut. Lihat Harun Nasution, Ensiklopedi Islam di Indonesia (Jakarta: Departemen Agama Republik Indonesia, 1993), 1186.
} 
terhadap persoalan-persoalan yang sedang dihadapi oleh masyarakat. Kapasitasnya sebagai ulama ahli hadis mendorongnya untuk merespon keadaan tersebut dengan menulis kitab Risalah Ahl al-Sunnah wa al-Jamā'ah.

\section{b. Sistematika dan Metode Penulisan}

Dalam penyusunan kitab hadis, dikenal ada empat macam sistematika, yaitu: pertama, sistematika sahịh dan sunan, yaitu kitab hadis yang disusun berdasarkan kitab-kitab tertentu, setiap kitab terdiri dari beberapa bab, sistematika ini juga dikenal dengan istilah sistematika fiqhiyah. Misalnya ditulis dalam kitab-kitab taharah, salat dan sebagainya, setiap kitab-kitab tersebut terdiri dari beberapa bab. Kedua, sistematika musnad, yaitu kitab hadis yang ditulis berdasarkan nama periwayat pertama yang menerima dari Nabi. Ketiga, sistematika kamus, yaitu kitab hadis yang ditulis berdasarkan huruf abjad hijaiyah. Keempat, kitab hadis yang disusun berdasarkan lima bagian-bagian tertentu seperti perintah, larangan, kabar, ibadah dan af'āl secara umum. $^{15}$

Adapun metode penulisan kitab ini dengan menggunakan metode sharh, yaitu mengutip suatu hadis kemudian menjelaskannya secara panjang lebar. Lebih rinci, dalam metode ini biasanya pengarang akan menempuh langkah-langkah sebagai berikut: Pertama, mengutip hadis dengan menyebutkan rawi pertama dan mukharrij-nya. Kedua, mengutip hadis dengan menuliskan matannya saja. Ketiga, mengutip hadis dengan menyebutkan perawi pertama saja.

Sistematika yang dipakai kitab hadis Risalah Ahl al-Sunnah wa al-Jamā'ah mengikuti sistematika sahịh dan sunan. Dalam sistematika ini, Hasyim Asy'ari membagi kepada beberapa bab dan setiap bab diberi judulnya masing-masing. Bagian awal dilengkapi dengan muqaddimah, setelah itu barulah bagian isi. Kitab ini terbagi kepada sepuluh bab yang diawali oleh bab tentang akidah (sunnah dan bid'ah) dan ditutup dengan

\footnotetext{
${ }^{15}$ M. Hasybi Ash-Shiddieqi, Sejarah dan Pengantar Ilmu Hadis (Jakarta: Bulan Bintang, 1980), 116-117.
}

pembahasan tentang pembahasan orang yang sudah meninggal. Gambaran umum isi kitab ini adalah sebagai berikut:

\begin{tabular}{|c|c|c|}
\hline No & Bab & $\begin{array}{l}\text { Juml } \\
\text { ah } \\
\text { Hadis }\end{array}$ \\
\hline 1 & Penjelasan sunnah dan bid'ah & 2 \\
\hline 2 & $\begin{array}{l}\text { Masyarakat Jawa dan Ahl } \\
\text { Sunnah wa al-Jamá'ah, awal } \\
\text { muncul dan penyebaran } \\
\text { bid'ah di Jawa, macam- } \\
\text { macam bentuk bid'ah yang } \\
\text { ada sekarang }\end{array}$ & 1 \\
\hline 3 & $\begin{array}{l}\text { Penjelasan ulama salaf } \\
\text { tentang al-asăwad al-a'zam } \\
\text { (golongan paling besar), serta } \\
\text { pentingnya berpegang terha- } \\
\text { dap imam yang empat }\end{array}$ & 1 \\
\hline 4 & $\begin{array}{l}\text { Penjelasan tentang kebolehan } \\
\text { taqlid bagi orang yang tidak } \\
\text { mampu berijtihad }\end{array}$ & 0 \\
\hline 5 & $\begin{array}{l}\text { Urgensi kehati-hatian dalam } \\
\text { berpedoman terhadap agama } \\
\text { dan ilmu }\end{array}$ & 5 \\
\hline 6 & $\begin{array}{lll}\text { Penjelasan hadis tentang } \\
\text { tanda-tanda hari kiamat dan } \\
\text { hilangnya ilmu dan } \\
\text { menjamurnya kebodohan }\end{array}$ & 9 \\
\hline 7 & $\begin{array}{l}\text { Balasan bagi orang-orang } \\
\text { yang mengajak kepada } \\
\text { kesesatan dan contoh yang } \\
\text { buruk }\end{array}$ & 5 \\
\hline 8 & $\begin{array}{l}\text { Penjelasan hadis tentang } \\
\text { firqah }\end{array}$ & 2 \\
\hline 9 & $\begin{array}{l}\text { Penjelasan tentang tanda- } \\
\text { tanda datangnya hari kiamat }\end{array}$ & 33 \\
\hline \multirow[t]{2}{*}{10} & $\begin{array}{l}\text { Penjelasan tentang kematian } \\
\text { dan alam sesudahnya }\end{array}$ & 4 \\
\hline & Total Hadis & 62 \\
\hline
\end{tabular}

Setelah melakukan langkah-langkah di atas, pengarang selanjutnya merujuk kepada kitab-kitab sharh hadis seperti kitab fath albari karya Ibn Hajar al-Asqalani. Merujuk kepada pendapat ulama dan terakhir merujuk kepada madzhab yang empat (Hanafi, Maliki, Syafi'i dan Hanbali). 


\section{c. Ahlus Sunnah wal Jama'ah dan Bid'ah}

Pasca kepulangannya ke tanah air, Hasyim Asy'ari melihat berbagai pemikiran dan praktik keagamaan Muslim Indonesia khususnya Jawa telah bergeser. Sebelumnya, Muslim Jawa dikenal sebagai penganut agama yang taat terhadap mazhab Imam Syafi'i dalam bidang fikih. Sementara dalam bidang teologi mengikuti mazhab Imam Abu Hasan al-Ash'ari, serta Imam Ghazali dan Abu alHasan al-Shadhali dalam bidang tasawuf. Disamping itu, Hasyim Asy'ari juga banyak melihat fenomena-fenomena di masyarakat yang sudah menyimpang dan tidak sesuai lagi dengan ajaran Islam, seperti menyebarnya aliran Syi'ah yang dianggap sebagai aliran sesat, zindiq bahkan kufr, munculnya faham al-ibahiyūn (liberalisme dan hedonisme) dan lain-lain.

Berdasarkan realitas umat Islam ketika itu, maka Hasyim Asy'ari merasa perlu untuk "meluruskan" kembali pemahaman umat Islam yang mulai menyimpang dari keberagamaan yang semestinya. Kitab Risālah Ahl al-Sunnah wa al-Jamā'ah yang ditulisnya merupakan sebuah respon dari keadaan ketika itu. Hasyim Asy'ari perlu memberikan penjelasan kepada umat Islam tentang pentingnya memegang teguh ajaran agama Islam yang bersumber dari Alquran dan Hadis dan menjauhkan dari perbuatan-perbuatan yang tidak sesuai dengan sumber ajaran Islam di atas.

Secara etimologis, kata al-ahl berfungsi sebagai badal nisbah, karena dikaitkan dengan kata al-sunnah yang berarti orang-orang yang berpaham Sunni (al-sunniyyūn). Kata alsunnah disamping memiliki arti al-hadith, juga bersinonim dengan kata al-sirah, altariqah, al-tabi'ah dan al-shari'ah. Menurut Hasyim Asy'ari, sunnah secara bahasa berarti jalan, meskipun jalan itu tidak disukai. Sementara menurut istilah sunnah adalah sebutan bagi jalan yang disukai dan dijalani dalam agama sebagaimana dipraktikkan oleh Rasulullah SAW atau Sahabat. Pengertian ini didasarkan pada hadis Nabi SAW yang berbunyi:

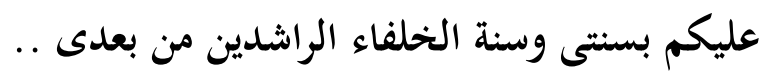

Kalian harus berpegang pada tradisiku dan tradisi penggantiku.

Menurut adat kebiasaan, sunnah adalah sesuatu yang dipraktikkan secara kontinu (terus-menerus) oleh sosok yang menjadi panutan baik seorang Nabi atau wali. ${ }^{16}$

Secara sekilas, pandangan Hasyim Asy'ari tentang Ahl al-Sunnah wa al-Jamā'ah mencerminkan corak metodologi konvensional yang digunakan oleh para teolog (mutakallimin) Muslim era klasik. Dengan menggunakan identifikasi yang dilakukan oleh Fazlurrahman, corak metodologi dimaksud bercirikan hal-hal sebagai berikut: (1) bertujuan menetapkan akidah "aliran yang selamat" (al-firqah al-najiyyah) melawan aliran sesat; (2) menjelaskan perbedaan di antara berbagai aliran; (3) menjelaskan pendapat orang-orang Islam dan perbedaan di antara mereka yang salat; (4) menyajikan akidah berbagai aliran kaum Muslimin dan orang-orang musyrik; (5) mengikuti kaidah-kaidah golongan salaf secara konsisten; mengutamakan al-itba' (kepengikutan terhadap pendahulu) tanpa pengembangan (al-ibda'); dan (6) menghimpun kandungan buku-buku klasik yang berserakan. ${ }^{17}$

Bagi Hasyim Asy'ari, mengajukan rumusan naratif Ahl al-Sunnah wa al-Jamā'ah menjadi penting dilakukan. Dalam kitab Risālah ahl Sunnah wa al-Jamā'ah, Hasyim Asy'ari mengutip hadis riwayat Abu Dawud sebagai landasan teologis pendapatnya ini:

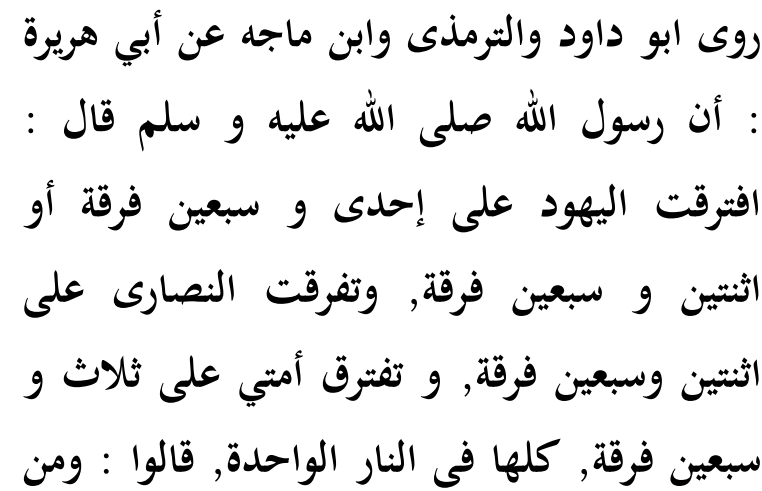

\footnotetext{
${ }^{16}$ M. Hasyim Asy-'Ari, Risalah Ahl Al-Sunnah Wa Al-Jamā'ah Fï Hadith Al Mawta Wa Ashrat Al- Sa'ah Wa Bayan Mafhum Al-Sunnah Wa Al-Bid'ah (Jombang: Maktabah al-Turath Al-Islami, n.d.).

${ }^{17}$ Zuhri, Pemikiran KH. Hasyim Asy'ari tentang Ahl Al- Sunnah Wa Al Jama'ah, 142.
} 


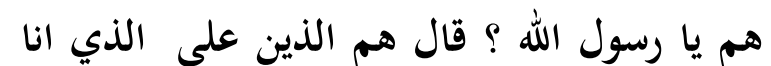

18

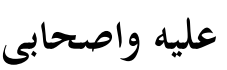

Abū Dawud a1-Ṭirmidhì dan lbn Majah meriwayatkan dari Abū Hurairah RA bahwasanya Rasulullah saw bersabda bersabda: umat Yahudi akan terpecah menjadi 71 golongan, umat Nasrani akan terpecah menjadi 73 golongan, semua golongan akan masuk neraka kecuali satu.

Kemudian para sahabat bertanya siapakah mereka Ya Rasulullah, Rasulullah menjawab mereka adalah golonganku dan para sahabatku yang ada di dalamnya.

Teks hadis di atas memang tidak secara eksplisit menyebut kata "ahl al-Sunnah wa alJamā'ah”. Namun, dengan merujuk pendapat Shihab al-Hafaji, Hasyim Asy'ari menegaskan bahwa firqah al-najiyyah yang dimaksud dalam teks hadis adalah, "ahl al-Sunnah wa al-Jamā'ah".

Persoalan lain yang menjadi sorotan Hasyim Asy'ari adalah bid'ah. Mengenai bid'ah ini merupakan lawan dari kata sunnah, dengan merujuk pendapat Syaikh Zaruq dalam kitab Uddah al-Murid, Hasyim Asy'ari menjelaskan bahwa bid'ah adalah munculnya perkara baru dalam agama yang kemudian mirip dengan bagian agama, padahal sebenarnya bukan, baik secara formal maupun hakikat.

Menurut KH Hasyim, bid'ah dapat diartikan sebagai: ${ }^{19}$

Mendatangkan atau menciptakan suatu perkara baru di dalam agama, dan meyakininya sebagai bagian dari ajaran agama, padahal perkara tersebut sebenarnya tidak menjadi bagian dan ajaran agama, baik dari sisi bentuk maupun hakikatnya.

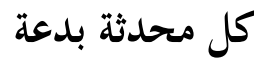

Setiap perkara yang baru adalah bid'ah

${ }^{18} \mathrm{Abu}$ Dawud, Aun Al-Ma'bud Syarh Sunan Abi Dawud (Tt.: Dar al-Fikr, n.d.). No. 3980, 195, dalam CD-ROM Mausu'ah al-Hadis al-Syarif al-Kutub alTis'ah, Global Islamic Software, 1997.

${ }^{19}$ Asy-'Ari, Risalah Ahl Al-Sunnah Wa Al-Jamā'ah Fï Hadith Al Mawta Wa Ashrat Al- Sa'ah Wa Bayan Mafhum Al-Sunnah Wa Al-Bid'ah, 6.

\section{من احدث فى امرنا هذا ما ليس منه فهو رد20}

Barangsiapa yang memunculkan perkara baru dalam urusan kami (agama) yang tidak merupakan bagian dari agama itu, maka perkara tersebut ditolak.

Berbeda dengan kalangan yang menganggap bahwa, seluruh perkara baru adalah bid'ah dan sekaligus sesat tanpa terkecuali, bagi Hasyim Asy'ari tidak semua muhadathat berstatus bid'ah. Dalam bahasa berbeda dapat dinyatakan, tidak semua muhadathat adalah bid'ah, meskipun tidak terdapat dalil yang jelas (sarih), namun bisa jadi tetap bersandar pada syari'at. Sandaran dimaksud dapat dengan menggunakan berbagai pendekatan metodologis yang ada, misalnya melalu mekanisme penganalogian (qiyas). Hal ini berarti, penerjemahan terhadap teks-teks otoritatif (hadis) tentang bid'ah harus menggunakan pendekatan yang lebih menyeluruh atau tidak hanya tekstual semata.

Mengutip pandangan Syaikh Zaruq, Hasyim Asy'ari menjelaskan bahwa bid'ah ada tiga macam: Pertama, bid'ah sarih (yang jelas dan terang). Yaitu bid'ah sesuatu yang ditetapkan tanpa memiliki landasan syari'at, baik yang wajib, yang sunnah maupun lainnya. Kedua, bid'ah izāfiyyah (relasional), yaitu bid'ah yang disandarkan pada suatu hal jika ia dapat selamat dari penyandaran ini, maka tidak dianggap sah memperdebatkannya. Ketiga, bid'ah khiläfiyyah (yang diperselisihkan), yaitu perdebatan sudut pandang perbedaan argument (dalil). Salah satu pihak akan mengatakannya sebagai bid'ah, sedangkan yang lainnya mengatakan sebagai sunnah.

Kemudian mengutip pandangan Ibn Abd al-Salam membagi bid'ah menjadi enam hukum. Pertama, bid'ah, yaitu melakukan sesuatu yang tidak dikenal pada masa nabi. Kedua, wajib, seperti belajar ilmu Nahwu dan kata-kata asing dalam Alquran dan sunnah. Ketiga, haram, seperti aliran Qadariyah, Jabariyah dan Mujassimah. Keempat, mandub, seperti membangun sekolah. Kelima, makruh,

${ }^{20}$ Imam Muslim, "Ṣahih Muslim, Kitab Al-Aqdiyah, Bab Naqụlu Al-Ahkam Al-Bațilah" (Global Islamic Software, 1997). 
seperti menghias masjid dan mushaf. Keenam, mubah, seperti berjabat tangan setelah salat asar dan subuh.

Bila dicermati pembagian bid'ah, Hasyim Asy'ari memaknai pengertian bid'ah secara umum, yakni segala hal yang baru yang diadaadakan sesudah Nabi, baik dalam urusan ibadah maupun adat. Selanjutnya dan pengertian umum ini bid'ah diseleksi dan diklasifikasi tingkatan hukumnya.

Dalam menentukan apakah sebuah perkara agama itu bid'ah atau tidak, Hasyim Asy'ari tidak memukul rata, akan tetapi memberikan aturan atau norma-norma tertentu sehingga suatu perkara dikatakan bid'ah atau tidak. Adapun norma-norma untuk menilai perkara itu bid'ah atau tidak adalah sebagai berikut: pertama, mempertimbangkan perkara baru tersebut. Jika perkara baru tersebut sebagian besar didukung oleh dalil-dalil syar'i yang kuat, maka perkara tersebut tidak dapat dinilai bid'ah. Tetapi apabila perkara baru tersebut tidak didukung sama sekali oleh dalil syara' maka perkara tersebut dianggap sesat dan batil.

Kedua, mempertimbangkan legalitas kaidah-kaidah para imam dan ulama salaf yang mempraktikkan sunnah. Perkara baru yang bertentangan dengan kaidah tersebut akan ditolak dalam segala aspeknya. Jika suatu perkara tersebut ada dasarya tetapi tidak ada informasi yang menyatakan praktik para ulama salaf. Ketiga, norma perbedaan (klasifikasi) berdasarkan bukti-bukti hukum. Norma ini terbagi menjadi enam, yaitu sunnah, haram, makruh, menyalahi keutama'an (khilaf alawla) dan mubah. Setiap perkara yang terkait dengan hukum asal tersebut dengan dasar yang benar dan jelas, maka perkara tersebut diikutkan pada hukum itu. Jika tidak demikian, maka dikatakan sebagal bid'ah. ${ }^{21}$

Contoh perkara bid'ah yang ada di masyarakat menurut Hasyim Asy'ari yaitu, mencuri atau merampas harta rakyat melalui bujukan rayuan konsumerisme, wisata belanja atau keberanian semisal pasar malam dan

\footnotetext{
${ }^{21}$ Didik Wahyudi, Tafsir Bid'ah dan Implementasinya dalam Ibadah (Yogyakarta: UIN Sunan Kalijaga, 2008), 47-49.
}

pesta-pesta pertunjukan serta perjudian semacam bola ketangkasan dan lain-lain adalah bid'ah yang buruk. Sedangkan perkaraperkara seperti penggunaan tasbih, melafazkan niat, tahlilan atau mendo'akan orang yang meninggal tanpa suatu apapun yang menghalangi, termasuk ziarah kubur, bukanlah perkara bid'ah. ${ }^{22}$

\section{SIMPULAN}

Pemikiran Hasyim Asy'ari dalam bidang hadis memberikan pengaruh yang cukup besar di masanya. Di mana ketika itu, kajian hadis di Indonesia belum begitu banyak, bahkan bisa dikatakan melalui kitabnya Risālah ahl al-Sunnah wa al-Jamā'ah fî Hadith al Mawta wa Ashrat al- Sa'ah wa Bayan Mafhum alSunnah wa al-Bid'ah beliau telah berhasil meletakkan dasar-dasar kajian hadis dan solusi teologis bagi persoalan yang sedang dihadapi masyarakat. Hal ini dilatarbelakangi oleh kondisi sosial ketika itu yang mengundang kekhawatirannya, sehingga kapasitasnya sebagai seorang ahli hadis merasa memiliki tanggungjawab untuk menyelesaikan masalah ini. Melalui kitabnya di atas, Hasyim Asy'ari juga telah berhasil memperkenalkan kajian hadis kepada umat Islam di Indonesia yang diambil lansung dari kitab-kitab hadis primer meskipun tidak semuanya.

Hasyim Asy'ari memang bukanlah seorang ulama hadis metodologis yang mengkaji hadis dari aspek kualitas dan kuantitasnya. Kajian hadis Hasyim Asy'ari sebagai seorang ulama dan ahli dalam bidang hadis hanya sebatas upaya menyelesaikan persoalan-persoalan yang sedang dihadapi oleh masyarakat ketika itu. Hadis-hadis yang ia tulis di dalam kitabnya tidak diberi penjelasan tentang kualitasnya. Hal ini sangatlah wajar, mengingat ketika itu ulumul hadis belum berkembang di Indonesia. Sebagai perkenalan terhadap kajian hadis, upaya yang telah dilakukan oleh Hasyim Asy'ari ketika itu adalah yang terbaik di masanya.

\footnotetext{
${ }^{22}$ Asy-'Ari, Risalah Ahl Al-Sunnah Wa Al-Jamā'ah Fi Hadith Al Mawta Wa Ashrat Al- Sa'ah Wa Bayan
} Mafhum Al-Sunnah Wa Al-Bid'ah. 8. 


\section{DAFTAR PUSTAKA}

Al-Tirmashi, Muhammad Mahfud Ibn Abd Allah. Manhaj Dhawi Al-Nazar. Surabaya: Ahmad Ibn Sa'ad Ibn Nabhan, 1974.

Ash-Shiddieqi, M. Hasybi. Sejarah Dan Pengantar Ilmu Hadis. Jakarta: Bulan Bintang, 1980.

Asy'ari, M. Hasyim. Risalah Ahl Al-Sunnah Wa Al-Jamā'ah Fì Hadith Al-Mawta Wa Ashrat Al-Sa'ah Wa Bayan Mafhum AlSunnah Wa Al-Bid'ah. Jombang: Maktabah al-Turath Al-Islami, t.t.

Azra, Azyumardi. Jaringan Ulama Timur Tengah Dan Kepulauan Nusantara Abad XVII \& XVIII; Akar Pembaruan Islam Di Indonesia. Jakarta: Kencana, 2013.

Dawud, Abū. 'Aun Al-Ma'būd Sharh Sunan Abi Dawud. t.k.: Dār al-Fikr, t.t.

Dhofier, Zamakhsyari. Tradisi Pesantren Studi Tentang Pandangan Hidup Kyai. Jakarta: LP3ES, 1994.

Khalil, Ahmad. Islam Jawa, Sufisme Dalam Etika Dan Tradisi Jawa. Malang: UIN Malang Press, 2008.

Khuluq, Latiful. Kebangunan Ulama "Biografi KH. Hasyim Asy'ari." Yogyakarta: LKiS, 2000.

Muslim, Imam. "Șahịh Muslim, Kitāb AlAqdiyah, Bab Naqḍlu Al-Ahkam AlBatilah.” Global Islamic Software, 1997.
Nasution, Harun. Ensiklopedi Islam Di Indonesia. Jakarta: Departemen Agama Republik Indonesia, 1993.

. Pembaharuan Dalam Islam; Sejarah Pemikiran Dan Gerakan. Cetakan ke. Jakarta: Bulan Bintang, 2003.

Nata, Abuddin. Tokoh-Tokoh Pembaharuan Pendidikan Islam Di Indonesia. Jakarta: Raja Grafindo Persada, 2005.

Nizar, Samsul, Ramayulis. Ensiklopedi Tokoh Pendidikan Islam Di Indonesia. Jakarta: Raja Grafindo Pustaka, 2005.

Roziqin, Badiatul. 101 Jejak Tokoh Islam Indonesia. Yogyakarta: e-Nusantara, 2009.

Suprapto, M. Bibit. Ensiklopedi Ulama Nusantara. Jakarta: Gelegar Media Indonesia, 2009.

Wahyudi, Didik. Tafsir Bid'ah Dan Implementasinya Dalam Ibadah. Yogyakarta: UIN Sunan Kalijaga, 2008.

Zuhri, Achmad Muhibbin. Pemikiran KH. Hasyim Asy'ari Tentang Ahl Al- Sunnah Wa Al Jama'ah. Surabaya: Khalista, 2010. 